\title{
Feminisme Dalam Web Series "Sore-Istri Dari Masa Depan" (Analisis Wacana Sara Mills)
}

\author{
Finy Fitrya Basarah \\ Fakultas Ilmu Komunikasi, Universitas Mercu Buana \\ Jl. Meruya Selatan No. 1, Kembangan, Jakarta Barat 11650, Indonesia \\ finy.basarah@mercubuana.ac.id
}

Received 29 June 2019, Revised 26 August 2019, Accepted 25 September 2019

\begin{abstract}
Web series was an alternative entertainment for the people of Indonesia. One of the titles, SORE-Istri dari Masa Depan, was the story of Sore, a time traveller, who came to the past to meet Jo, a man who would become his future husband. SORE-Istri dari Masa Depan was also one of the Indonesian web series that had been watched by more than two million viewers since the first episode. This research used the theory of feminism to see how feminists emerged and portrayed in this web series. While the method was discourse analysis from Sara Mills, who looked at how the position of the subject-object and the writers-readers were described through this web series. The result of this research was being a woman meant more aware of healthy life compared to men; had the power to regulate men's lives, changed it to be better, healthier; and more able to campaign "Healthy Life" than men.
\end{abstract}

Keywords : Web series, Feminism, Sara Mills Discourse Analysis.

\begin{abstract}
Abstrak : Web series adalah salah satu alternatif hiburan bagi masyarakat Indonesia. Salah satu judulnya, SORE-Istri dari Masa Depan, bercerita tentang Sore, seorang time traveller, yang datang ke masa lalu untuk menemui Jo, laki-laki yang bakal menjadi suaminya kelak. SORE-Istri dari Masa Depan ini juga menjadi salah satu web series Indonesia yang ditonton oleh lebih dari 2 juta viewers sejak episode pertama. Penelitian ini mempergunakan teori feminisme untuk melihat bagaimana feminis yang muncul dan tergambarkan dalam web series ini. Sedangkan metode yang dipergunakan adalah analisis wacana dari Sara Mills, yang melihat bagaimana posisi subjek-objek dan penulispembaca digambarkan melalui web series ini. Adapun hasil dari penelitian ini adalah menjadi seorang perempuan berarti lebih sadar akan hidup sehat dibandingkan dengan laki-laki; memiliki kuasa untuk mengatur hidup laki-laki, merubahnya menjadi lebih baik, lebih sehat; dan lebih bisa mengkampanyekan "Hidup Sehat" dibandingkan laki-laki.
\end{abstract}

Kata Kunci : Web series, Feminisme, Analisis Wacana Sara Mills

\section{PENDAHULUAN}

Web series saat ini menjadi salah satu alternatif hiburan masyarakat Indonesia. Cukup dengan melalui smart phone, web series bisa dinikmati kapan saja melalui media sosial YouTube atau LINE. Pengertian web series sendiri adalah " $A$ web series is a series of scripted or non-scripted videos, generally in episodic form, released on the internet and part of the web television medium, which first emerged in the late 1990s and become more prominent in the early 2000s."].

Malam Minggu Miko bisa disebut sebagai salah satu web series yang cukup terkenal di Indonesia. Web series ini merupakan karya Raditya Dika, dibintangi oleh Raditya Dika sendiri, Ryan Andriandhy, dan

\footnotetext{
${ }^{1}$ https://en.wikipedia.org/wiki/Web_series. Diakses pada 24.11.18, pukul 12.39

${ }^{2}$ https://dailysocial.id/post/tren-web-series-indonesia-semakinkreatif. Diakses pada 26.11.18, pukul 14.26.
}

Hadian Saputra. Malam Minggu Miko rilis melalui akun YouTube Raditya Dika².

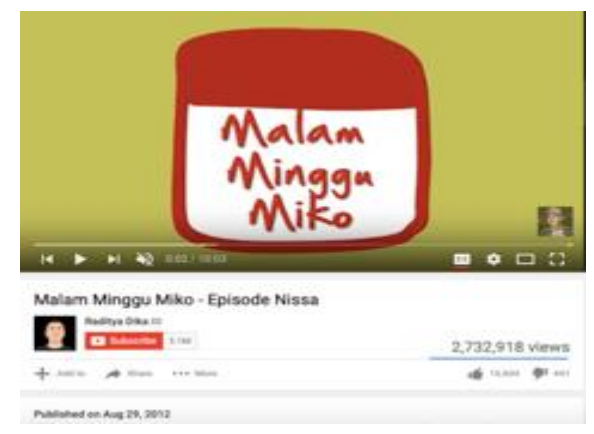

Gambar 1. Web Series Malam Minggu Miko

\footnotetext{
${ }^{3}$ https://www.youtube.com/watch?v=q210QZtMz6Q\&list=PLZN2 wZjY_38Ck5ugfPQi4cFG8tj58zy1g. Diakses pada 26.11.18, pukul 14.27.
} 
Saat ini ada beberapa judul web series yang dinilai memiliki cerita yang bagus, salah satunya adalah SORE-Istri dari Masa Depan. Web series ini dibintangi oleh Tika Bravani dan Dion Wiyoko, mengambil lokasi di Italia, dan disponsori oleh brand Tropicana Slim Stevia ${ }^{4}$. Episode pertama web series ini bahkan ditonton oleh lebih dari 2 juta orang viewers ${ }^{5}$. Jumlah viewers yang tidak sedikit ini sedikit banyak menunjukkan bahwa web series SORE ini memiliki cukup banyak penggemar terutama di Indonesia sendiri.

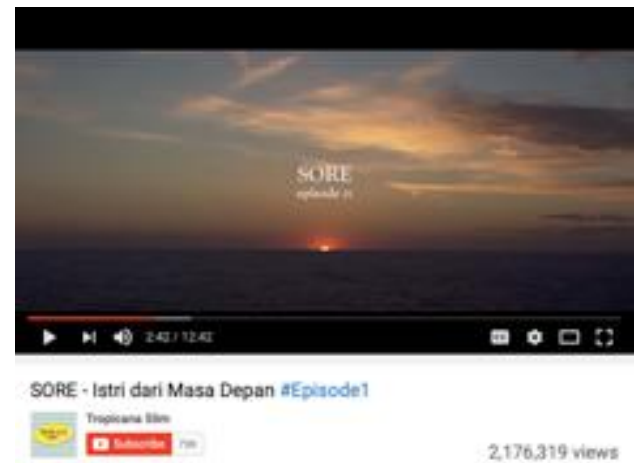

Gambar 2. Web Series "SORE-Istri Dari Masa Depan"

Secara singkat SORE-Istri dari Masa Depan ini bercerita tentang seorang perempuan bernama Sore, seorang time traveller, yang datang ke masa lalu untuk menemui Jo, calon suaminya kelak. Tak hanya itu, dalam cerita ini Sore selain menemani hari-hari Jo juga "menyelamatkan" Jo dengan mengarahkannya ke pola hidup yang lebih baik, demi kesehatan Jo sendiri.

Awalnya Jo memang tidak memiliki pola hidup sehat. Kebiasaannya begadang demi menyelesaikan pekerjaannya ditambah dengan kebiasaan merokok dan mengkonsumsi alkohol sekaligus tidak berolah raga dan tidak mengkonsumsi makanan sehat menyebabkan Sore merasa khawatir akan kesehatan dan hidup Jo. Pola hidup sehat ini bisa saja dibilang salah satu kampanye yang hendak disampaikan oleh pihak sponsor, Tropicana Slim Stevia. Sore datang dari masa depan memang untuk menyelamatkan hidup Jo, supaya Jo memiliki harapan hidup yang lebih panjang.

Cerita ini memang bisa dibilang ber-genre DramaFantasi, mengapa? Karena sepanjang pengetahuan peneliti, tidak ada yang namanya memutar balikan waktu baik kembali ke masa lalu atau pindah ke masa depan.

Selain itu bagaimana Sore mengatur kehidupan Jo tidak hanya menggambarkan kehidupan perempuan tetapi juga menunjukkan adanya dominasi sosok perempuan, Sore, dalam mengatur kehidupan lakilaki, Jo, yang mana hal tersebut sebetulnya dilakukan demi kepentingan mereka bersama sebagai keluarga.

\footnotetext{
${ }^{4}$ https://www.kincir.com/movie/series/deretan-web-seriesindonesia-yang-enggak-murahan. Diakses pada 24.11.18, pukul 14.14 .
}

Dalam web series ini perempuanlah yang diceritakan menentukan kelangsungan sebuah keluarga.

Cerita drama tapi "tidak mungkin" inilah yang menarik perhatian peneliti untuk menjadikannya bahan kajian penelitian, walaupun melihatnya dari perspektif bagaimana peran Sore dalam menyelamatkan hidup seorang Jo.

Dengan mempergunakan perspektif feminis dan mempergunakan analisis wacana Sara Mills, maka penelitian ini bertujuan untuk mengetahui bagaimana feminsme dalam web series SORE-Istri dari Masa Depan. Metode ini dipakai karena analisis wacana Sara-Mills merupakan metode yang memposisikan bagaimana subjek dan objek digambarkan dalam teks, juga bagaimana posisi penulis-pembaca (atau komunikator-komunikan) digambarkan dalam teks. Hal tersebut yang memang akan dibahas dalam penelitian ini, peneliti ingin melihat bagaimana posisi tokoh SORE sebagai subjek dan Jo sebagai objek digambarkan dalam penelitian.

Berdasarkan latar belakang permasalahan di atas, maka fokus dalam penelitian ini adalah "Bagaimana feminsme dalam web series SORE-Istri dari Masa Depan?"

Tujuan penelitian ini adalah untuk mengetahui bagaimana feminsme dalam web series SORE-Istri dari Masa Depan. Adapun sistematika penulisan ini terdiri dari Pendahulaun (Latar Belakang, Formulasi Masalah, Tujuan, dan Sistematika Penulisan), Kajian Pustaka, Metodologi Penelitian, Hasil Penelitian dan Analisis, dan Kesimpulan.

\section{KAJIAN PUSTAKA}

Berikut ini adalah definisi dari media sosial yang berasal dari berbagai literatur penelitian (lihat Fuchs, 2014, dalam Nasrullah, 2016). ${ }^{6}$

1. Menurut Mandilbergh (2012), media sosial adalah media yang mewadahi kerja sama di antara pengguna yang menghasilkan konten (usergenerated content).

2. Menurut Shirky (2008), media sosial dan perangkat lunak sosial merupakan alat untuk meningkatkan kemampuan pengguna untuk berbagi (to share), bekerja sama (to co-operate), di antara pengguna dan melakukan tindakan secara kolektif yang semuanya berada di luar kerangka institusional maupun organisasi.

3. Boyd (2009) menjelaskan media sosial sebagai kumpulan perangkat lunak yang memungkinkan individu maupun komunitas untuk berkumpul, berbagi, berkomunikasi, dan dalam kasus tertentu saling berkolaborasi atau bermain. Media sosial memiliki kekuatan pada user-generated content (UGC) di mana konten dihasilkan oleh pengguna, bukan oleh editor sebagaimana di instutusi media massa.

\footnotetext{
${ }^{5}$ https://www.youtube.com/watch?v=PY3_jveYQSI. Diakses pada 24.11.18, pukul 14.09.

${ }^{6}$ Rully Nasrullah. Media Sosial, Perspektif Komunikasi, Budaya, dan Sosioteknologi. Bandung: PT Remaja Rosdakarya. 2016: 11.
} 
4. Menurut Van Dijk (2013), media sosial adalah platform media yang memfokuskan pada eksistensi pengguna yang menfasilitasi mereka dalam beraktivitas maupun berkolaborasi. Karena itu, media sosial dapat dilihat sebagai medium (fasilitator) online yang menguatkan hubungan antarpengguna sekaligus sebagai sebuah ikatan sosial.

5. Meike dan Young (2012) mengartikan kata media sosial sebagai konvergensi antara komunikasi personal dalam arti saling berbagi di antara individu (to be shared one-to-one) dan media publik untuk berbagi kepada siapa saja tanpa ada kekhususan individu.

Meski karakteristik media siber bisa dilihat melalui media sosial, media sosial memiliki karakteristik khusus yang tidak dimiliki oleh beberapa jenis media siber lainnya. Ada batasan-batasan dan ciri khusus tertentu yang hanya dimiliki oleh media sosial dibanding dengan media lainnya. Adapun karakteristik media sosial, yaitu: 1) Jaringan (Network); 2) Informasi (Information); 3) Arsip (Archive); 4) Interaksi (Interactivity); 5) Simulasi sosial (Simulation of Society); dan 6) Konten oleh pengguna (User-generated content). ${ }^{7}$

\section{Feminisme}

Tidaklah mudah memberikan pengertian yang tepat dan diterima oleh semua pihak perihal apa yang dimaksud dengan feminisme atau gerakan feminisme (perempuan) itu. Kesulitan itu, salah satunya, karena terdapat begitu banyak model, ragam, serta tujuan gerakan perempuan. Kendati demikian, di sini kita akan berupaya sedapat mungkin menjelaskan apa itu yang dimaksud dengan feminisme. ${ }^{8}$

Feminisme, di sini, dapat dipahami sebagai kajian (paradigma) sekaligus metodologi yang bertujuan untuk mengungkapkan bahwa dalam realitas sosial, budaya, politik, dan sebagainya mendapat ketimpangan gender, relasi yang timpang antara lakilaki dan perempuan, ketindasan perempuan, stereotipe yang tidak benar yang dilekatkan kepada kaum perempuan dan sebagainya (Hallows, Joanne, 2010, Arivia, 2003: Tong, 1998, dalam Lubis, 2016). ${ }^{9}$ Di samping sebagai kajian dan metodologi feminisme juga merupakan sebuah gerakan. Oleh sebab itu, feminisme tidak semata-mata dimengerti sebagai teori, cara pandang, atau sistem pemikiran, namun juga dimengerti sebagai sebuah gerakan (baca: memiliki dimensi praxis). ${ }^{10}$

Lantaran feminisme tidak semata-mata dimengerti sebagai teori, cara pandang atau sistem pemikiran

\footnotetext{
${ }^{7}$ Ibid. hal 16.

${ }^{8}$ Akhyar Yusuf Lubis. Pemikiran Kritis Kontemporer. Dari Teori Kritis, Cultural Studies, Feminisme, Postkolonial Hingga Multikulturalisme. Jakarta: PT RajaGrafindo Persada. 2016: 9596.

${ }^{9}$ Ibid. hal 96.

${ }^{10}$ Ibid.

11 Ibid.
}

namun dimengerti pula sebagai sebuah gerakan, maka dengan demikian ia juga memiliki tujuan (kepentingan). Adapun tujuan dari feminisme atau kajian perempuan tersebut antara lain: (1) menyediakan informasi dan analisis (penelitian) mengenai kehidupan kaum perempuan; (2) mengupayakan perubahan sosial serta menghilangkan ketidaksetaraan gender dan subordinasi kaum perempuan; (3) menjadikan diri sebagai sebuah bentuk kritik terhadap ilmu pengetahuan yang telah ada (baca: Modernisasi/positivisme); dan (4) memperlihatkan bagaimana perspektif kaum perempuan mengenai ilmu pengetahuan yang belum terlihat dalam ilmu pengetahuan sebelumnya (Jackson, Stevi dan Jakie Jones, 1998, dalam Lubis, 2016). ${ }^{11}$

\section{Analisis Wacana dan Analisis Wacan Kritis}

Wacana adalah praksis sosial dalam bentuk interaksi simbolis yang bisa terungkap dalam pembicaraan, tulisan, kial, diagram, film, atau musik (Fairclough, 2010 dan M. Bloor \& Thomas, 2007, dalam Haryatmoko, 2017). ${ }^{12}$

Dalam definisi Ricoeur, wacana memiliki empat unsur, yaitu: 1) ada subjek yang menyatakan; 2) kepada siapa disampaikan; 3) dunia atau wahan yang mau direpresentasikan; dan 4) temporalitas atau konteks waktu (Ricoeur, 1986, dalam Haryatmoko, 2017). ${ }^{13}$ Pemahaman mengenai unsur-unsur Ricoeur ini bisa membantu menjelaskan mengapa oleh Foucault dan Wetherell, wacana dilihat sebagai praksis sosial karena wacana sudah merupakan tindakan. Wacana bisa dianalisis dalam kerangka aktivitas, relasi sosial, dan teknologi komunikasi. Maka ada aktivitas yang bentuk utamanya adalah wacana (kuliah, rapat, ibadah, wawancara), dan ada wacana hanya sebagai aktivitas penunjang (sepak bola, kerja bakti, membangun rumah). ${ }^{14}$

Dalam kajian-kajian wacana atau discourse, seringkali peneliti studi media di Indonesia hanya memahami teks-teks media yang tertulis atau terdokumentasi saja, dan belum mempunyai kepekaan yang tinggi untuk mengangkat praktik-praktik kehidupan sosial sebagai sebuah teks yang menarik untuk diamati sebagai sebuah wacana atau discourse study. Kebiasaan untuk menjadikan kehidupan seharihari masyarakat sebagai teks, barangkali lebih kaya dilakukan dalam tradisi Antropologi dengan metode etnografinya. ${ }^{15}$

Menurut Thwaites et al. (2002, dalam Ida, 2014) ${ }^{16}$, teks adalah kombinasi dari tanda-tanda atau signs. Tanda-tanda ini yang "bermain" dan memproduksi

\footnotetext{
${ }^{12}$ Haryatmoko. Critical Discourse Analysis (Analisis Wacana Kritis). Landasan Teori, Metodologi, dan Penerapan. Jakarta: PT RajaGrafindo Persada. 2017: 4

${ }^{13}$ Ibid. Hal 5.

14 Ibid.

15 Rachmah Ida. Metode Penelitian, Studi Media dan Kajian Budaya. Jakarta: Prenada Media Group. 2014: 63.

${ }^{16}$ Ibid. Hal. 63-64
} 
makna dalam suatu teks. Tanda/sign diartikan sebagai segala sesuatu yang menghasilkan makna. Tanda tidak hanya komentar yang dibuat oleh seseorang yang mengolah tanda menjadi bermakna, tetapi tanda juga adalah segala sesuatu yang ada di dunia ini. Tanda atau sign adalah merujuk pada sesuatu. Dengan kata lain, tanda mewakili atau menjadi referensi terhadap sesuatu sehingga menghasilkan makna. Tanda tidak hanya membawa makna, tetapi juga memproduksi makna. Pada kenyataannya tanda sendiri memproduksi banyak makna, tidak hanya satu makna per tanda, inilah kembali yang disebut sebagai polysemic tanda. Tanda menghasilkan multiple interpretasi bagi pemaknanya.

Berikut perbedaan antara analisis wacana dengan analisis wacana kritis $^{17}$ :

Tabel 1. Perbedaan analisis wacana (objektif) dengan analisis wacana kritis

\begin{tabular}{|c|c|c|c|}
\hline No & & $\begin{array}{c}\text { Analisis Wacana } \\
\text { (Objektif) }\end{array}$ & $\begin{array}{c}\text { Analisis } \\
\text { Wacana } \\
\text { Kritis } \\
\end{array}$ \\
\hline 1. & $\begin{array}{l}\text { Struktur } \\
\text { Pengetahua } \\
\mathrm{n}\end{array}$ & $\begin{array}{l}\text { Deskripsi tentang } \\
\text { fakta dengan } \\
\text { ambisi bebas } \\
\text { nilai; objektif. }\end{array}$ & $\begin{array}{l}\text { Pengembanga } \\
\text { n dari tradisi } \\
\text { ilmu sosial } \\
\text { kritis; tidak } \\
\text { bebas nilai; } \\
\text { subjek harus } \\
\text { ikut teribat. }\end{array}$ \\
\hline 2. & $\begin{array}{l}\text { Kerangka } \\
\text { Acuan }\end{array}$ & $\begin{array}{l}\text { Tidak mau } \\
\text { condong ke nilai } \\
\text { atau politik } \\
\text { tertentu; } \\
\text { mengambil jarak; } \\
\text { untuk } \\
\text { menjelaskan, } \\
\text { kontrol, prediksi. }\end{array}$ & $\begin{array}{l}\text { Dimotivasi } \\
\text { oleh tujuannya } \\
\text { memberi dasar } \\
\text { ilmiah bagi } \\
\text { pertanyaan } \\
\text { kritis terhadap } \\
\text { kehidupan } \\
\text { sosial dalam } \\
\text { rangka moral, } \\
\text { politik, } \\
\text { keadilan sosial } \\
\text { \& kekuasaan } \\
\text { (berpihak). }\end{array}$ \\
\hline 3. & Tujuan & $\begin{array}{l}\text { Memberdayakan } \\
\text { bentuk-bentuk } \\
\text { kehidupan sosial } \\
\text { agar bisa bekerja } \\
\text { lebih efektif } \\
\text { tanpa merasa } \\
\text { terlibat dalam } \\
\text { masalah moral } \\
\text { dan politik. }\end{array}$ & $\begin{array}{l}\text { Menumbuhkan } \\
\text { kesadaran } \\
\text { kritis dengan } \\
\text { membongkar } \\
\text { bentuk-bentuk } \\
\text { dominasi yang } \\
\text { disembunyika } \\
\mathrm{n} \rightarrow \text { menjadi } \\
\text { agent of } \\
\text { change. } \\
\text { Mendemistifik } \\
\text { asi bahasa } \\
\text { karena } \\
\text { membekukan } \\
\text { ideologi dan } \\
\text { jadi instrumen } \\
\text { kekuasaan. }\end{array}$ \\
\hline
\end{tabular}

${ }^{17}$ Haryatmoko. Op. Cit. Hal. 14.

${ }^{18}$ Aris Badara, Aris. 2014. Analisis Wacana. Teori, Metode, dan Penerapannya pada Wacana Media. Jakarta: Kencana Prenada Media Group. 2014: 50-51.

\begin{tabular}{ll}
\hline Menghasilkan \\
pengetahuan \\
untuk \\
melawan cara \\
memerintah \\
yang dominan \\
\hline
\end{tabular}

Riset ini sendiri termasuk ke dalam analisis wacana kritis, karena akan membongkar bentukbentuk dominasi yang ada di dalam teks media (sosial).

\section{Analisis Wacana Sara Mills}

Salah satu perhatian Sara Mills terhadap strategi wacana ialah bagaimana pembaca ditampilkan di dalam teks. Strategi tersebut berkaitan dengan pertanyaan bagaimanakah pembaca mengidentifikasi dan menempatkan pembaca pada salah satu posisi dan memengaruhi bagaimana teks itu hendak dipahami dan bagaimana pula aktor sosial ini ditempatkan. Pada akhirnya cara penceritaan dan posisi-posisi yang ditempatkan dan ditampilkan dalam teks ini membuat satu pihak menjadi legitimate dan pihak lain illegitimate. ${ }^{18}$

Mills berpandangan, dalam suatu teks posisi pembaca sangatlah penting dan haruslah diperhitungkan dalam teks. Menurut Mills, bahwa teks merupakan suatu hasil negosiasi antara penulis dan pembaca. Pandangan Mills itu dengan sendirinya menolak pandangan banyak ahli yang menempatkan dan mempelajari konteks semata dari sisi penulis, sementara sisi pembaca diabaikan. Mills membangun suatu model yang menghubungkan antara teks dan penulis di satu sisi dengan teks dan pembaca di sisi lain. ${ }^{19}$

Menurut Mills model ini mempunyai kelebihan, pertama, model seperti itu lebih komprehensif melihat teks bukan hanya berhubungan dengan faktor produksi melainkan juga resepsi. Kedua, posisi pembaca di sini ditempatkan di dalam posisi yang penting. Hal ini karena teks memang ditunjukkan untuk secara langsung atau tidak "berkomunikasi" dengan khalayak. Teks mempunyai ragam sapaan kepada khalayak. $^{20}$

Dalam penelitian ini, kerangka analisis wacana Sara Mills ini mengalami penyesuaian di mana Posisi Penulis - Pembaca diganti menjadi Posisi Komunikator-Komunikan.

\section{METODOLOGI PENELITIAN} Paradigma

Paradigma penelitian yang dipergunakan adalah paradigma kritis, yang mengungkapkan ideologi dari isi (konten) web series berjudul SORE-Istri dari Masa Depan.

\footnotetext{
${ }^{19}$ Ibid. Hal 51

${ }^{20}$ Ibid.
} 
Penelitian-penelitian dalam ranah studi-studi media dan budaya ini lebih memfokuskan kajiannya pada upaya-upaya untuk mengungkap resistensi dan ideologi yang tersembunyi di balik penciptaan imageimage dalam film, misalnya, produksi teks-teks berita, produksi gambar-gambar iklan, dan potret-potret identitas di televisi kita. ${ }^{21}$

\section{Pendekatan}

Pendekatan yang dianggap sesuai dengan riset ini adalah kualitatif. Penelitian kualitatif memiliki ciriciri, yaitu: 1) konteks dan setting alamiah (naturalistic); 2) bertujuan untuk mendapatkan pemahaman yang mendalam tentang suatu fenomena; 3) keterlibatan secara mendalam serta hubungan erat antara peneliti dengan subjek yang diteliti; 4) teknik pengumpulan data yang khas kualitatif tanpa adanya perlakuan (treatment) atau memanipulasi variabel; 5) adanya penggalian nilai (values) yang terkandung dari suatu perilaku; 6) bersifat fleksibel; dan 7) tingkat akurasi data dipengaruhi oleh hubungan antara peneliti dengan subjek penelitian. ${ }^{22}$

\section{Metode}

Dalam penelitian ini akan diteliti mengenai feminisme dalam web series SORE-Istri dari Masa Depan dengan mempergunakan analisis wacana Sara Mills.

\section{Teknik Pengumpulan Data}

Untuk melengkapi pengumpulan data ini, maka peneliti memerlukan beberapa data pendukung yang bersumber dari data primer dan data sekunder, maka dari itu peneliti menggunakan dua macam teknik pengumpulan data yaitu:

1) Data Primer. Data yang diperoleh adalah konten kesembilan episode web series SORE-Istri dari Masa Depan.

2) Data Sekunder. Yaitu kumpulan data lain yang mendukung penelitian ini, yaitu studi kepustakaan (library research) yang berhubungan terhadap teori, informasi tentang hal-hal yang berkaitan dengan landasan teori, serta konsep-konsep ilmiah yang diperlukan pada saat analisis.

\section{Definisi Konsep}

1) Web series, yaitu salah satu alternatif hiburan yang ditayangkan di media YouTube.

2) Feminisme, yaitu sebuah gerakan di mana perempuan mempunyai peran yang tidak kalah dengan laki-laki.

3) Analisis Wacana, yaitu kerangkan analisis wacana Sara Mills sebagai metode riset.

\section{HASIL PENELITIAN DAN ANALISIS Hasil Penelitian}

\footnotetext{
${ }^{21}$ Rachmah Ida. Op. Cit. Hal. 11

${ }^{22}$ Haris Herdiansyah, Wawancara, observasi, dan focus groups sebagai instrumen penggalian data kualitatif. Jakarta: PT RajaGrafindo Persada. 2013: 16-23.
}

Scene 1. Kehidupan Jo Tinggal Seorang Diri di Italia Jauh dari Keluarga

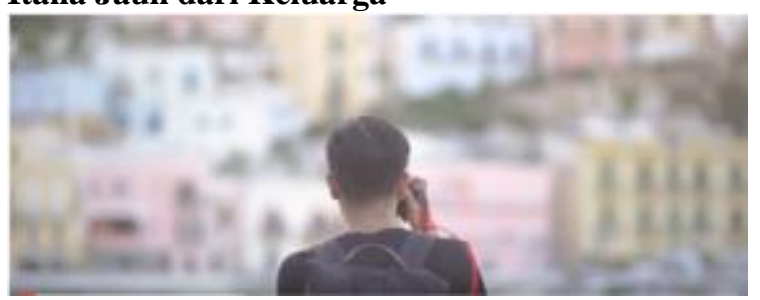

Gambar 1a

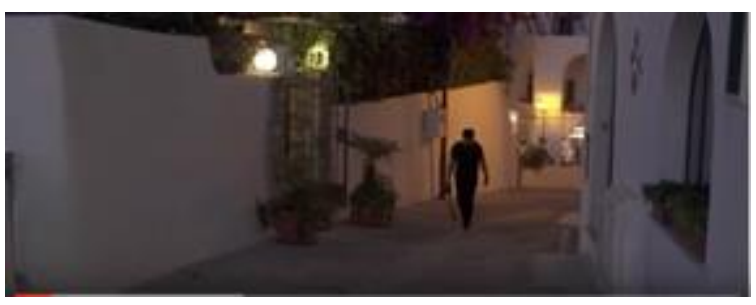

Gambar 1b

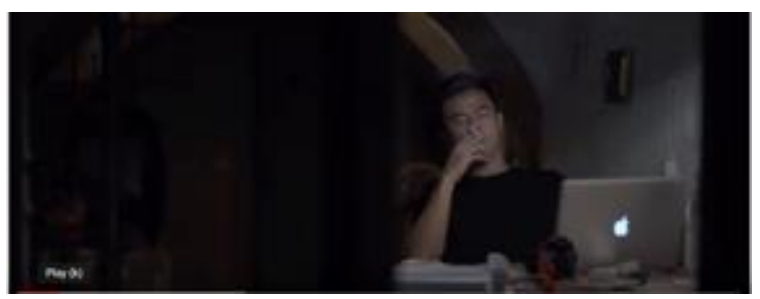

Gambar 1c

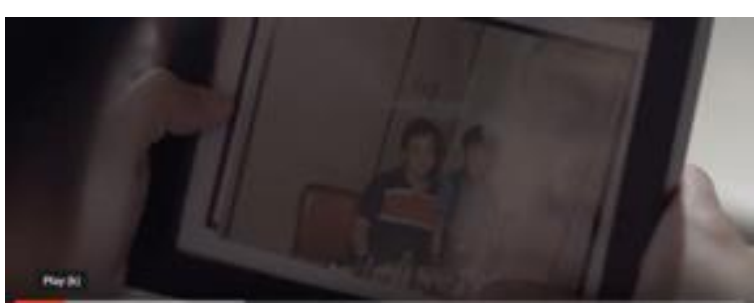

Gambar 1d

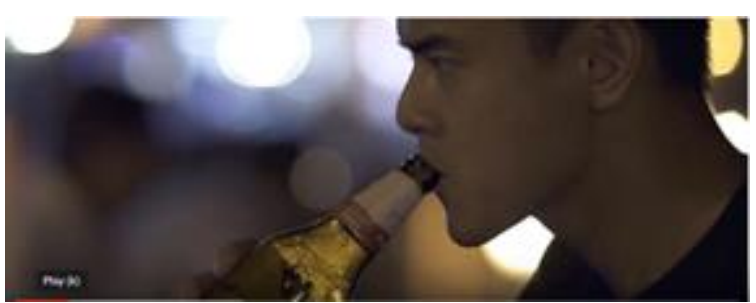

Gambar 1e

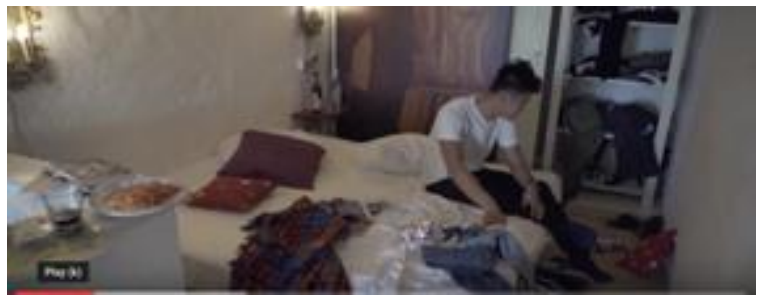

Gambar 1f 
Tabel 2. Kehidupan Jo Tinggal Seorang Diri di Italia Jauh dari Keluarga

\section{Posisi Subjek-Objek}

Diceritakan Jo (objek), seorang pemuda asal Indonesia yang pergi merantau ke negeri orang. Jo tinggal sendiri jauh dari keluarga. Gaya hidup Jo sangatlah tidak sehat, mulai dari kebiasaan merokok, minum minuman beralkohol, sampai rumahnya yang dibiarkan berantakan tidak tertata dengan rapi. Dari sini bisa dilihat bahwa Jo tidak bisa mengurus dirinya sendiri karena gaya hidup yang tidak sehat tersebut. Mungkin Jo bisa mandiri secara ekonomi karena memiliki pekerjaan di negeri orang, namun Jo tidak bisa mampu menjaga dirinya sendiri. Jo butuh bantuan orang lain.

\section{Posisi Komunikator-Komunikan}

Sebagai komunikan peneliti melihat bahwa sosok Jo butuh teman untuk bisa menjadi lebih baik, gaya hidup lebih baik, lebih sehat. Apabila Jo hidup seorang diri sebetulnya Jo tidak mampu mengurus dirinya sendiri. Jangankan mengurus kesehatannya, menata tempat tinggalnya pun Jo terlihat tidak mampu. Suatu hal yang tidak wajar apabila sosok laki-laki dianggap tidak mampu mengurus dirinya sendiri.

\section{Scene 2. Sosok Perempuan (Sore) yang Tiba-tiba Muncul dalam Kehidupan Jo}

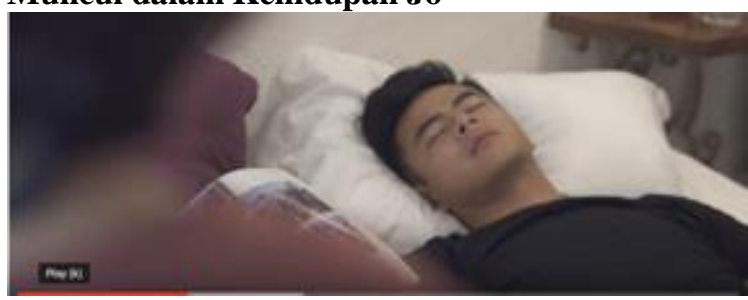

Gambar 2a

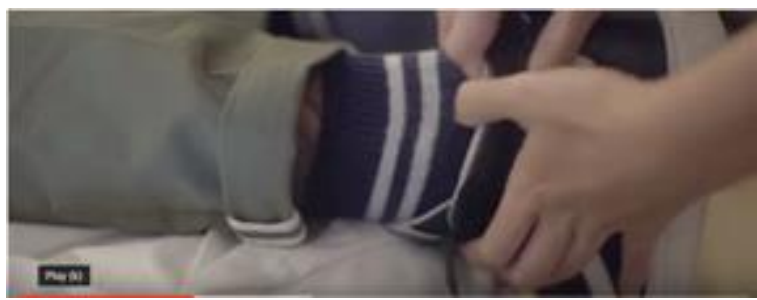

Gambar 2b

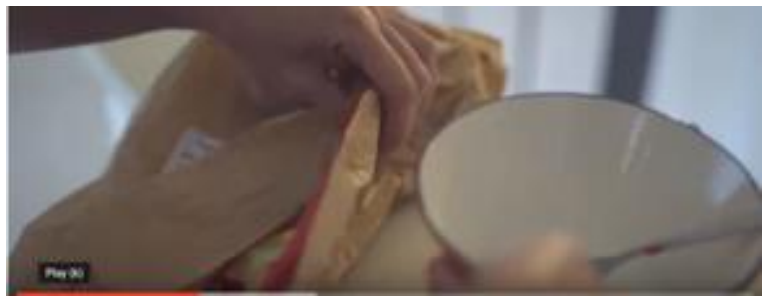

Gambar 2c

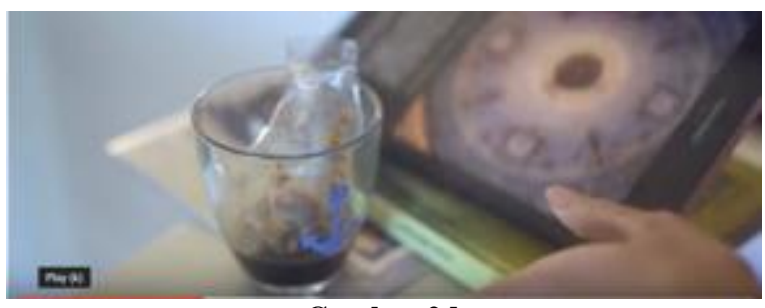

Gambar 2d

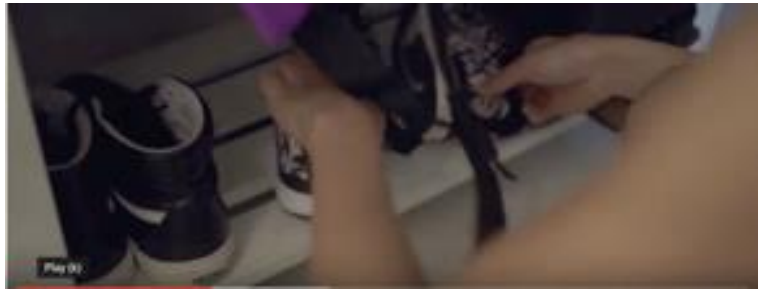

Gambar 2e

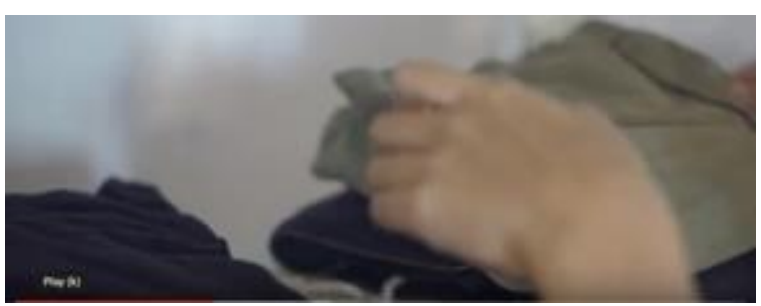

Gambar 2f

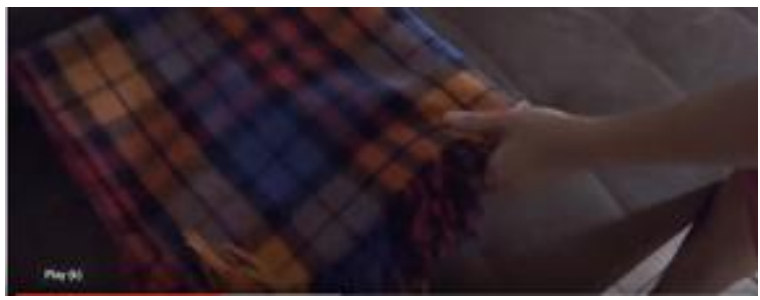

Gambar 2g

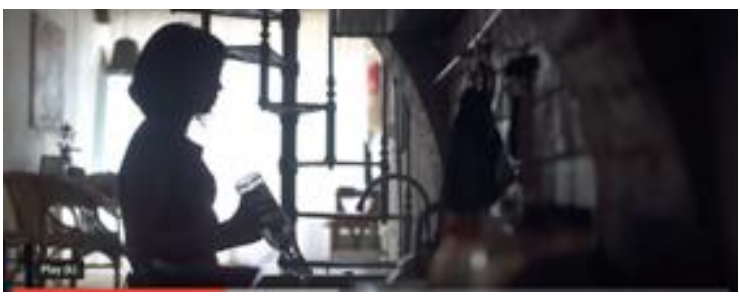

Gambar 2h

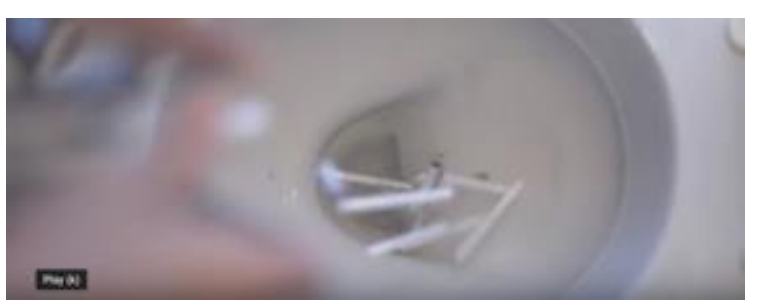

Gambar 2i

Tabel 3. Sosok perempuan (Sore) yang tiba-tiba muncul dalam kehidupan Jo

\section{Posisi Subjek-Objek}

Sosok perempuan tiba-tiba muncul dalam kehidupan Jo. Perempuan ini (subjek) membantu Jo (objek) setidaknya untuk menjadi lebih baik. Apa yang dilakukan perempuan ini antara lain merapikan pakaian dan sepatu Jo di lemari, merapikan rumah, membuang sampah dari makanan yang tidak sehat, dan membuang alkohol dan rokok yang menjadi kebiasaan buruk Jo. Jo (objek) disini membutuhkan bantuan dari perempuan (subjek) supaya memperoleh hidup yang lebih sehat, lebih baik.

\section{Posisi Komunikator-Komunikan}

Komunikan sebagai peneliti melihat bahwa di sini sosok perempuan bisa membantu seorang laki-laki untuk memulai hidup yang lebih baik, lebih sehat. Kebiasaan 
sosok Jo (laki-laki) yang mengkonsumsi makanan tidak sehat (junk food), ditambah dengan kebiasaan mengkonsumsi alkohol dan merokok bisa dikendalikan untuk tidak diulang kembali, dan yang mengendalikannya tersebut adalah sosok perempuan. Sosok perempuan ini tanpa takut membuang minuman beralkohol dan rokok yang dimiliki Jo. Terdapat pembenaran apa yang dilakukan oleh perempuan (Sore) terhadap laki-laki (Jo), terutama membuang barangbarang tanpa seizin pemiliknya.

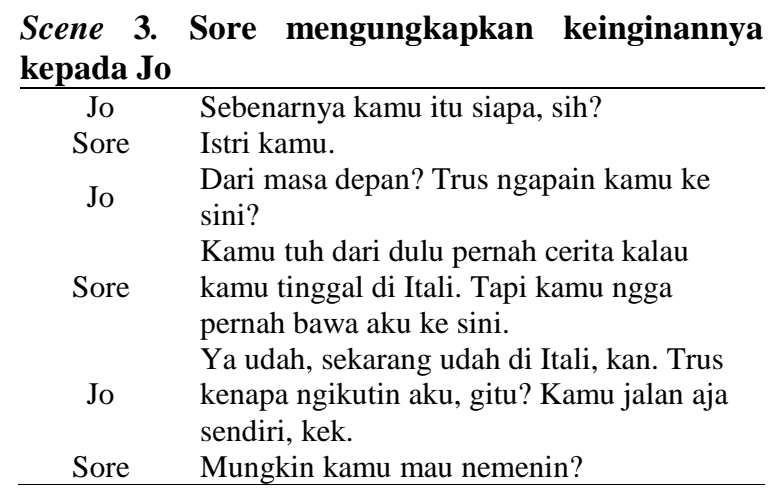

Tabel 4. Sore mengungkapkan keinginannya kepada Jo

\section{Posisi Subjek-Objek}

Sebagai subjek, Sore (perempuan), tahu apa yang ia mau. Pertama ia mengungkapkan jati dirinya dan kemudian mengungkapkan apa yang diinginkannya. Sore tidak canggung untuk meminta Jo (objek, laki-laki) untuk menemaninya jalan-jalan di tempat yang baru ia singgahi. Sebagai perempuan, Sore (subjek) memiliki rasa kepercayaan diri yang cukup tinggi dengan meminta seorang laki-laki, Jo (objek), yang baru mengenalnya saat itu (meskipun sosok Jo sendiri tidak asing untuk Sore).

\section{Posisi Komunikator- Komunikan}

Sebagai komunikan, peneliti melihat bahwa di sini sosok perempuan (Sore) bisa mengungkapkan apa yang diinginkannya, walaupun mereka baru bertemu. Hal tersebut terjadi karena Jo sendiri bagi Sore bukanlah sosok yang asing, dan di sini Sore memiliki misi tertentu untuk Jo yang belum disampaikannya; alasan mengapa ia datang dari masa depan untuk menemui Jo, yang ia bilang adalah suaminya. Sebetulnya sangatlah tidak wajar apabila seorang perempuan yang dianggap baru mengenal laki-laki malah meminta laki-laki tersebut untuk menemaninya, namun tidak dalam pemikiran perempuan dalam scene ini.

\section{Scene 4. Sore mengatur menu makanan Jo}

\begin{tabular}{cl}
\hline Jo & $\begin{array}{l}\text { Sirloin medium, please.. } \\
\text { Sore }\end{array}$ \\
$\begin{array}{c}\text { Oh, no, no, no, no... wait... hmm.. ah, two } \\
\text { salad and garlic bread, please.. }\end{array}$ \\
\hline
\end{tabular}

Tabel 5. Sore mengatur menu makanan Jo

\section{Posisi Subjek-Objek}

Sore (subjek, perempuan), mengatur apa yang akan dikonsumsi oleh Jo (objek, laki-laki). Subjek di sini tidak mengizinkan objek untuk mengkonsumsi menu makanan yang objek inginkan, justru subjek malah membatalkannya dan memilihkan menu makanan yang sama dengan subjek, tanpa persetujuan dari objek. Dan apa yang dipilihkan oleh subjek tidak dibantah oleh objek, walaupun objek tampak keberatan.

\section{Posisi Komunikator-Komunikan}

Sebagai komunikan, peneliti melihat bahwa di sini perempuan mengatur apa yang harus dikonsumsi oleh laki-laki, bahkan tanpa meminta persetujuan terlebih dahulu. Padahal sebelumnya, laki-laki tersebut sudah memilih apa yang ia inginkan, yang mana kemudian dibatalkan oleh si perempuan. Pengendalian oleh perempuan di sini dibenarkan karena sang laki-laki pun tidak mengajukan keberatan sama sekali. Laki-laki menerima begitu saja pilihan dari perempuan, walaupun ia terlihat keberatan. Padahal laki-laki tersebut bisa saja mengajukan keberatannya dan kembali bersikukuh kepada pilihannya di awal, namun tidak dilakukannya. Sang laki-laki menerima begitu saja apa yang sudah dipilihkan oleh sang perempuan.

\section{Scene 5. Sore mengatur pertemuan pertamanya dengan Jo

$\begin{array}{cl}\text { Sore } & \begin{array}{l}\text { Akhir bulan ini kamu harus balik, ya, } \\ \text { kenalan, deketin aku. Harus berani, ya. }\end{array} \\ \text { Nonti aku ajarin, deh, caranya. } \\ \text { (mengernyitkan kening) }\end{array}$

Tabel 6. Sore mengatur pertemuan pertamanya dengan Jo

\section{Posisi Subjek-Objek}

Sore sebagai subjek (perempuan) meminta Jo (objek, laki-laki), untuk datang dan berkenalan dengannya akhir bulan ini, di Indonesia. Subjek pun meminta objek untuk mendekatinya. Subjek di sini memberi semacam perintah (menyuruh) objek untuk melakukan apa yang diinginkan oleh subjek. Bahkan di sini subjek berkata akan mengajari objek cara untuk mendekati subjek, supaya mereka akhirnya bisa dekat satu sama lain, dan kemudian menikah.

\section{Posisi Komunikator-Komunikan}

Sebagai komunikan sekaligus peneliti di sini melihat bahwa sebagai perempuan sosok Sore memiliki hak untuk menyuruh laki-laki melakukan apa yang ia inginkan. Sang laki-laki (Jo) pun (lagi-lagi) tidak membantah apa yang diperintahkan perempuan. Pengendalian oleh perempuan atas laki-laki di sini dibenarkan seolah-olah sang perempuan lah yang mengatur hidup si laki-laki. Sosok laki-laki (Jo) seolaholah tidak memiliki kendali atas hidupnya sendiri, bahkan untuk urusan perjodohan. Dengan meminta si laki-laki untuk menemuinya pada akhir bulan, menunjukkan bahwa si perempuan lah yang sebenarnya menginginkan mereka akhirnya menikah.

\section{Scene 6. Sore mengatur jam kerja dan waktu tidur} Jo

$\begin{array}{cl}\text { Sore } & \begin{array}{l}\text { Kerjanya ngga bisa besok pagi aja? Besok } \\ \text { ngga usah jalan-jalan pagi, deh. }\end{array} \\ \text { Jo } & \text { Ya ngga bisa. Kerja tuh enaknya malam. } \\ \text { Sore } & \text { Udah pernah coba kerja pagi-pagi banget, } \\ & \text { belum? } \\ \text { Jo } & \text { Kalau sampai pagi sih sering. } \\ \text { Sore } & \text { Ya beda. Coba, deh. Udah, ya, sekarang } \\ & \text { sikat gigi, trus siap-siap tidur. }\end{array}$


Tabel 7. Sore mengatur jam kerja dan waktu tidur Jo Posisi Subjek-Objek

Ketika objek (Jo, laki-laki) sedang mengerjakan pekerjaannya, subjek (Sore, perempuan) malah memintanya untuk berhenti, istirahat. Subjek di sini memiliki wewenang untuk memberikan perintah kepada objek untuk melakukan apa yang diinginkan subjek, merubah rutinitas objek menjadi sesuai dengan keinginan subjek.

\section{Posisi Komunikator-Komunikan}

Komunikan sekaligus peneliti di sini melihat bahwa perempuan (Sore) membujuk laki-laki (Jo) untuk istirahat. Tidak hanya itu, perempuan juga menyuruh laki-laki untuk menyikat giginya sebelum tidur. Perempuan membujuk laki-laki untuk merubah pola kerjanya; bukan bekerja di malam hari, sampai pagi, namun bekerja di mulai pada pagi-pagi sekali, dini hari. Di sini perempuan mengatur pola kerja dan jam istirahat laki-laki, menyuruhnya melakukan ritual (sikat gigi) sebelum tidur. Dan, lagi-lagi si laki-laki tidak membantahnya. Terdapat pembenaran atas apa yang sudah diperintahkan oleh perempuan kepada laki-laki dalam scene ini, di mana si laki-laki tidak membatahnya.

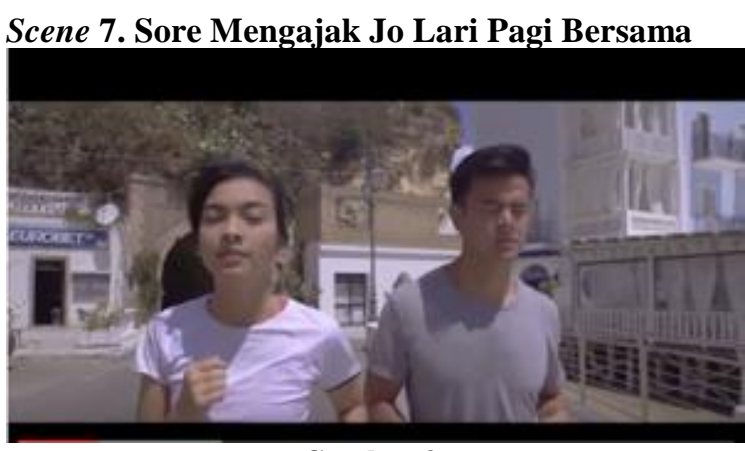

Gambar 3a

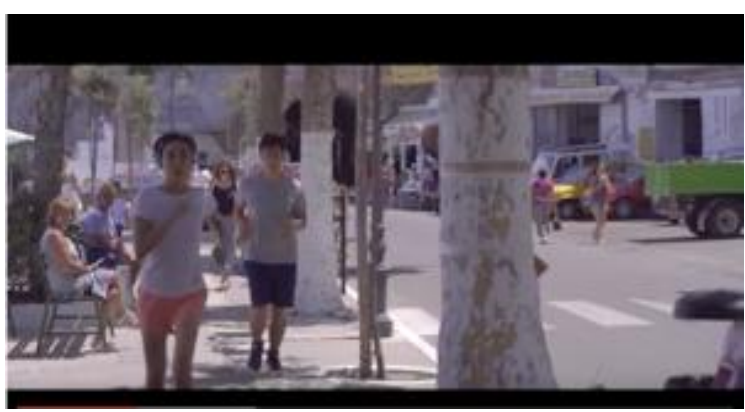

Gambar 3b

Tabel 8. Sore Mengajak Jo Lari Pagi Bersama

\section{Posisi Subjek-Objek}

Dengan sedikit terpaksa, objek (Jo, laki-laki) menerima ajakan subjek (Sore, perempuan), untuk melakukan aktivitas lari pagi. Posisi subjek berada di depan, artinya bukan hanya saja menjadi lead, namun juga mengarahkan jalur atau route lari pagi, sekaligus kapan berhenti. Di sini objek bersedia mengikuti apa yang diingkan oleh subjek, tanpa membantah.

\section{Posisi Komunikator-Komunikan}

Posisi perempuan (Sore) yang berada di depan di mana laki-laki (Jo) mengikutinya di belakang menunjukkan bahwa laki-laki di sini mengikuti keinginan perempuan.
Laki-laki menuruti apa kata perempuan. Laki-laki diarahkan oleh perempuan. Biasanya laki-laki lah yang berada dalam posisi lead dan perempuan dalam posisi follow. Dalam scene ini yang terjadi justru sebaliknya, dan hal tersebut tampak wajar-wajar saja. Di sinilah bagaimana komunikan sekaligus peneliti melihat situasi tersebut.

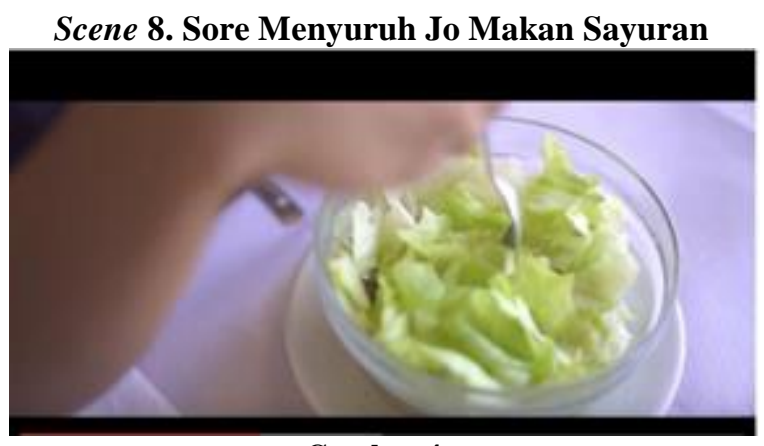

Gambar 4a

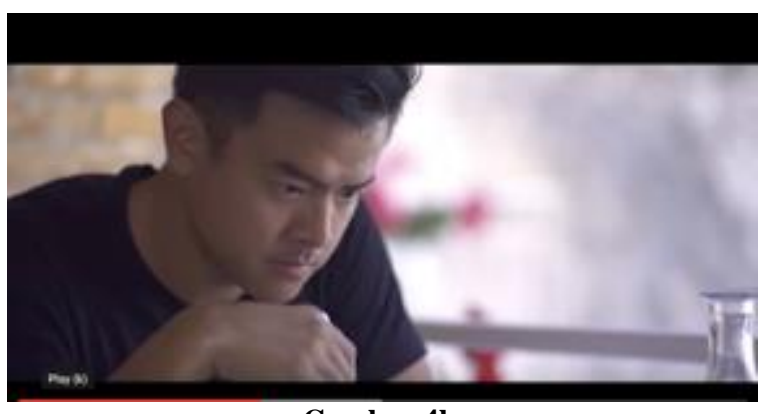

Gambar 4b

Tabel 9. Sore Menyuruh Jo Makan Sayuran Posisi Subjek-Objek Subjek (Sore, perempuan) menyuruh objek (Jo, laki-laki) untuk mengkonsumsi sayuran sebagai menu makannya. Objek mengikuti apa yang disuruh oleh subjek, walaupun melalui ekspresinya, objek menunjukkan rasa tidak senang. Laki-laki mengikuti apa yang diperintahkan oleh perempuan.

\section{Posisi Komunikator-Komunikan}

Sebagai komunikan, peneliti di sini melihat bahwa lakilaki (Jo) tidak membantah apa yang sudah dipilihkan oleh perempuan (Sore) untuknya. Laki-laki di sini mengikuti apa yang diinginkan si perempuan. Terdapat pembenaran atas apa yang dilakukan si perempuan terhadap laki-laki dalam scene ini, di mana laki-laki menuruti apa yang menjadi keinginan si perempuan, walaupun hal tersebut di luar kehendaknya (laki-laki melepaskan keinginannya sendiri demi menuruti keinginan si perempuan).

\section{Scene 9. Sore Memberikan Ultimatum Kepada Jo}

Dengerin, ya. Ngga ada satu pun orang yang

Jo bisa ngatur-ngatur aku sekalipun itu istri aku, tahu, ngga?

Harusnya kamu tuh tahu persis rasanya ditinggal ayah. Kalau kamu memang berniat

Sore untuk ninggalin aku, ninggalin Fajar (anak mereka), mati lebih dulu, ok! It's fine. Tapi kamu cuma perlu tahu satu hal, jangan kamu kenal sama aku, jangan pernah deketin aku, 
jangan kamu datang ke kehidupan aku, bikin aku terlalu sayang sama kamu, trus ujungujungnya kamu meninggal duluan!

Tabel 10. Sore memberikan ultimatum kepada Jo Posisi Subjek-Objek

Subjek (perempuan) memberikan ultimatum kepada objek (laki-laki) untuk tidak pernah membuat subjek terlalu sayang sama objek. Di sini subjek tidak ingin ditinggal terlalu dini oleh objek. Subjek tidak ingin dari awal didekati oleh objek, dibuat jatuh cinta, apabila pada akhirnya objek meninggalkannya terlebih dahulu, meninggalkan subjek dan anak mereka.

\section{Posisi Komunikator-Komunikan}

Walaupun (dialog) awalnya menunjukkan keberatan laki-laki atas pengaturan perempuan pada dirinya, namun akhirnya si perempuan malah memberikan ultimatum kepada si laki-laki. Perempuan ini tidak ingin didekati, jatuh cinta pada laki-laki yang akan meninggalkannya (dan anak mereka) terlalu dini.

Komunikan sekaligus peneliti di sini melihat sosok perempuan yang bisa menentukan apakah seseorang bisa mendekatinya atau tidak, bisa membuatnya jatuh cinta atau tidak. Ia memiliki kekuasaan untuk menolak atau menerima sosok laki-laki untuk hadir di dalam kehidupannya. Biasanya, laki-laki lah yang memilih perempuan, dan biasanya perempuan akan menuruti apa yang dikehendaki laki-laki. Namun perempuan di sini mempunyai hak untuk memilih, dan ia memilih laki-laki yang bisa hidup lebih lama bersamanya (tidak mati muda).

Scene 11. Jo yang akhirnya mau mengikuti keinginan Sore

Jo Kenapa ngga bilang dari awal aja aku bakal mati?

Tadinya aku ngga bakal bilang malah. Coba

Sore bayangin, hidup sehat karena takut mati. Kan ngga enak banget.

Jo Jadi tadi kamu udah nyerah?

Sore Abis kamu keras kepala, sih.

Jo Kalau gitu aku yang ngga bakal nyerah buat kamu.

Tabel 11. Jo yang akhirnya mau mengikuti keinginan Sore

\footnotetext{
Posisi Subjek-Objek

Sore (subjek) yang mengingkan Jo (objek) untuk berperilaku hidup sehat supaya mendapatkan kesempatan hidup lebih lama, akhirnya disepakati untuk dilakukan oleh objek. Apa yang dilakukan subjek selama ini terhadap objek bertujuan agar objek bisa menemani subjek lebih lama, karena tidak meninggal di usia yang relatif muda. Subjek menghendaki objek untuk mengubah perilaku dengan hidup lebih sehat, dan akhirnya objek menyetujuinya. Objek akan melakukan apa yang diinginkan oleh subjek.
}

Posisi Komunikator-Komunikan

Di sini komunikan sekaligus peneliti melihat bahwa lakilaki (Jo), menyadari bahwa hidupnya telah diselamatkan oleh perempuan (Sore). Tampak bahwa laki-laki di sini akhirnya mau mengikuti apa yang diingkan si perempuan dengan tujuan untuk bisa lebih lama menemani si perempuan dan juga anak laki-laki mereka. Laki-laki di sini bersedia merubah pola hidupnya menjadi lebih sehat sesuai arahan dan keinginan perempuan. Laki-laki di sini mau diatur oleh perempuan.

Scene 11. Jo mengikuti keinginan sore untuk kembali ke jakarta dan mencari Sore

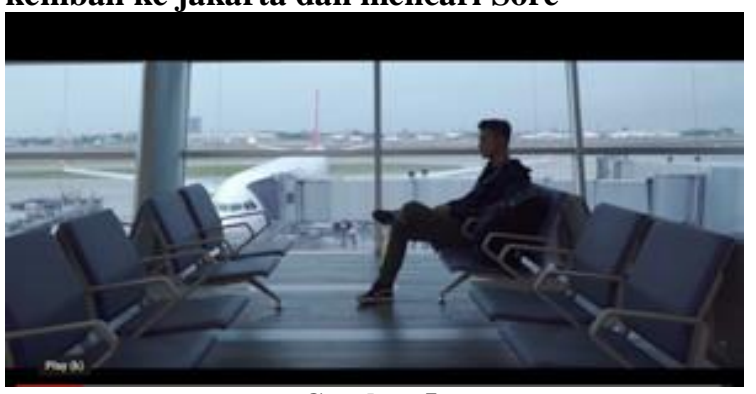

Gambar 5a

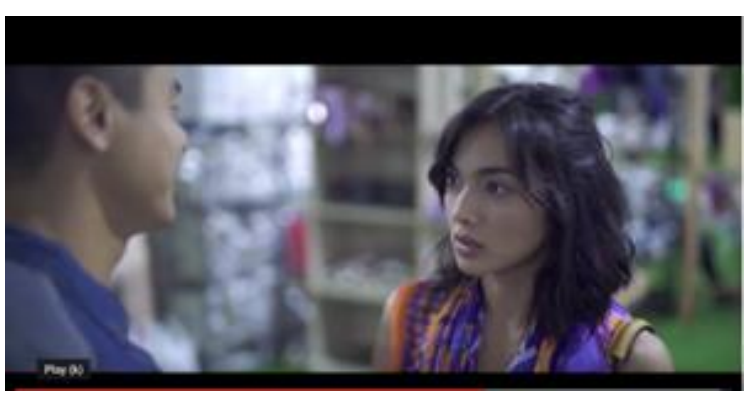

Gambar 5b

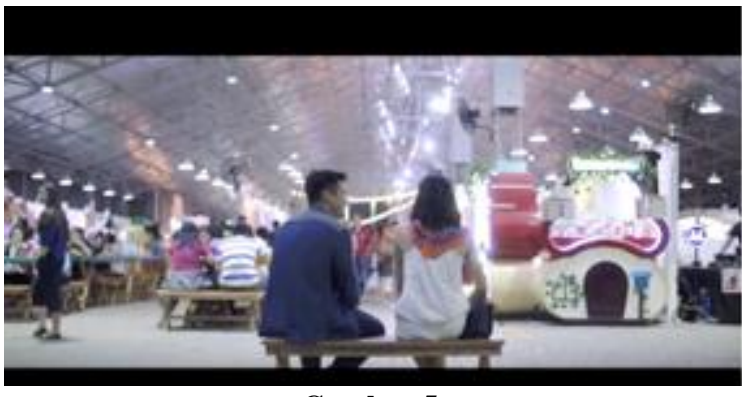

Gambar 5c

Tabel 12. Jo mengikuti keinginan sore untuk kembali ke jakarta dan mencari Sore

\section{Posisi Subjek-Objek}

Objek (Jo, laki-laki) mengikuti keinginan Subjek (Sore, perempuan) untuk datang ke Jakarta, mendekati untuk kemudian bisa dekat satu sama lain. Objek mengikuti keinginan subjek karena objek sebetulnya memang memerlukan subjek dalam hidupnya, bukan hanya sekedar menjadi teman hidup (pasangan) namun juga karena subjek bisa membantunya agar bisa hidup lebih lama.

\section{Posisi Komunikator-Komunikan}

Sebagai komunikan sekaligus peneliti di sini melihat bahwa sosok laki-laki ini (Jo) memerlukan sosok perempuan (Sore) untuk bisa membantunya menjalani hidup yang lebih baik, yaitu hidup sehat. Karena itulah mengapa laki-laki di sini mau mengikuti keinginan si perempuan untuk datang menemui, berkenalan dan untuk kemudian menikah. Selain itu juga dengan kedatangan si laki-laki menemui si perempuan juga menunjukkan bahwa si laki-laki akan mengikuti keinginan si 
perempuan untuk bisa hidup lebih sehat. Laki-laki di sini menyadari bahwa ia membutuhkan sosok perempuan ini.

\section{Analisis}

Secara umum feminisme berarti ada hak perempuan yang dikehendaki sama dengan laki-laki, bahwa perempuan mengingkan kesetaraan (equality). Perempuan tidak hanya menuruti kata orang lain, yaitu laki-laki, namun perempuan juga punya hak yang sama, yaitu menuruti kata hati atau keinginannya sendiri.

Sore adalah sosok perempuan yang memiliki keinginan sendiri. Keinginan tersebut adalah bahwa ia menginginkan sosok pendamping (suami) yang bisa menemani hidupnya lebih lama, alias tidak meninggal di usia relatif sangat muda. Ketika menghadapi kenyataan bahwa suaminya akan meninggalkannya di usia yang relatif muda, maka Sore memutuskan untuk melakukan perjalanan ke masa lalu (time travel) untuk menemui (calon) suaminya, Jo, membantunya memperbaiki pola hidupnya supaya memiliki kesempatan hidup lebih lama. Sore tahu apa yang dia mau dan berupaya untuk merealisasikannya.

Web series ini memang menceritakan adanya dominasi perempuan terhadap laki-laki, di mana perempuan mengatur hidup laki-laki, yaitu gaya hidup, pola makan, dan waktu tidur. Laki-laki dalam web series ini pun mau menuruti apa yang dikehendaki oleh perempuan, ia mau diatur apa yang harus ia makan, kapan ia harus tidur, dan kapan ia harus berolahraga. Kebiasaan buruk si laki-laki sebelumnya, yaitu merokok dan minum minuman beralkohol pun berhenti karena si perempuan menghendakinya. Dominasi perempuan di sini ditunjukkan oleh Sore atas Jo, laki-laki yang kelak akan menjadi suaminya.

Mengapa di sini laki-laki (Jo) mau diatur hidupnya oleh perempuan (Sore)? Karena dalam web series ini si laki-laki memang tidak mampu mengurusi hidupnya sendiri. Memang ia mandiri secara ekonomi karena memiliki pekerjaan, namun ia tidak mampu mengurus dirinya sendiri; tidak bisa menata rumah, tidak bisa memilih makanan sehat untuk dikonsumsi, dan bahkan tidak bisa memilih gaya hidup yang lebih sehat, lebih baik. Sosok laki-laki di sini membutuhkan orang lain, yang ternyata adalah sosok perempuan.

Ketika akhirnya si laki-laki berontak pada saat itu pun ia menyadari bahwa ia membutuhkan sosok perempuan ini, untuk bisa memiliki kesempatan hidup lebih lama. Si perempuan mengungkapkan bahwa ia tidak menginginkan pendamping hidup yang akan meninggalkannya begitu cepat, bahkan meninggalkannya dulu. Intinya, si perempuan tidak ingin ditinggalkan si laki-laki, bukan karena butuh, namun karena memang ia tidak mau.

Perempuan dalam web series ini memberikan ultimatum yang sepertinya wajar saja dilakukan oleh perempuan, ia adalah sosok perempuan yang tidak ingin didekati kalau akhirnya akan ditinggalkan. Mungkin kedengarannya egois, namun apa yang dilakukan si perempuan dalam web series ini, yaitu membantu si laki-laki, bukan hanya menyelamatkan dirinya sendiri, namun juga menyelamatkan si lakilaki dan anak laki-laki mereka kelak.

Bukan berarti si laki-laki di sini tidak memiliki kuasa atas dirinya dengan menuruti semua keinginan si perempuan kepada dirinya, namun si laki-laki ini pun menyadari bahwa ia membutuhkan sosok perempuan ini untuk membantu hidupnya ke arah yang lebih baik; mengkonsumsi makanan sehat, berolah raga, tidur tidak terlalu larut malam, dan menghentikan kebiasaan merokok dan minum minuman beralkohol.

Memiliki keinginan memang sudah sewajarnya untuk diutarakan dan/atau direalisasikan. Apa yang dilakukan Sore (perempuan) bukan hanya diutarakan namun juga direalisasikan. Intinya ia tidak ingin ditinggal suami (Jo) terlalu cepat. Sore adalah sosok perempuan yang yakin apa yang dilakukannya, ia sengaja kembali ke masa lalu karena ia yakin ia bisa menyelamatkan sang (calon) suami, Jo, dirinya sendiri, dan anak laki-laki mereka, Fajar. Dan apa yang diinginkannya pun terjadi; Jo merubah kebiasaan buruknya dan mencoba pola hidup lebih sehat.

Tampak bahwa apa yang dilakukan oleh sosok perempuan (Sore) memiliki dampak yaitu laki-laki (Jo) pada akhirnya mau menuruti keinginan si perempuan. Adapun hal tersebut dilakukan sebenarnya adalah untuk menyelamatkan keluarga mereka kelak. Walaupun nasib keluarga mereka berada di tangan laki-laki (Jo), yaitu dengan keingininan untuk mau merubah kebiasaannya ke arah yang lebih baik, lebih sehat, namun hal tersebut tidak mungkin dilakukan tanpa campur tangan dari perempuan (Sore).

Web series ini merupakan persembahan brand Tropicana Slim Stevia, yang mana produk dari Tropicana Slim sendiri secara umum sangat identik dengan produk makanan (maupun makanan pelengkap) yang sehat. Dengan slogan "Cegah Diabetes untuk Hidup Lebih Lama”, yang apabila dihubungkan dengan web series ini adalah terdapatnya kampanye untuk "Hidup Lebih Lama". Meninggal dunia dalam usia dini seperti yang dialami Jo (laki-laki) dalam web series ini dimaksud untuk dicegah agar Jo bisa "Hidup Lebih Lama".

Walaupun tidak ada satu pun produk dari brand Tropicana Slim Stevia yang muncul dalam web series ini, namun karena brand ini identik dengan "Hidup Sehat" maka perilaku yang ditampilkan dalam web series ini adalah "Hidup Sehat; gaya hidup dan pola makan yang sehat". Sosok perempuan yang mengatur laki-laki di sini menggambarkan bahwa yang melakukan kampanye di sini adalah si perempuan, bukan laki-laki. Menjadi perempuan dalam web series ini dianggap lebih mengerti manfaat "Hidup Sehat" dibandingkan dengan laki-laki. Perempuan dianggap lebih mampu mengkampanyekan "Hidup Sehat" dibandingkan dengan laki-laki. 
Mengutip salah satu quote dari Meghan Markle, Duchess of Sussex, yaitu "Women do not need to find their voice. They need to feel empowered to use it, and people need to be encouraged to listen to it", dalam web series ini ditunjukkan bahwa Sore, si perempuan, menjadi sosok yang mampu mengemukakan suaranya sendiri, yaitu mengenai "Kampanye Hidup Sehat", yang akhirnya mendapatkan dukungan dari Jo, lakilaki.

\section{KESIMPULAN}

Berikut kesimpulan yang bisa diambil dari penelitian ini:

1. Menjadi seorang perempuan berarti lebih sadar akan hidup sehat dibandingkan dengan laki-laki.

2. Menjadi seorang perempuan memiliki kuasa untuk mengatur hidup laki-laki, merubahnya menjadi lebih baik, lebih sehat.

3. Menjadi perempuan lebih bisa mengkampanyekan "Hidup Sehat" dibandingkan laki-laki.

\section{UCAPAN TERIMA KASIH}

Puji syukur kehadirat Allah SWT, Universitas Mercu Buana khususnya Lembaga Puslit untuk sumber pendanaan Riset TA 2018/2019, Fakultas Ilmu Komunikasi Universitas Mercu Buana, dan Universitas Pembangunan Jaya atas kesempatan yang diberikan untuk memfasilitasi luaran riset ini.

\section{DAFTAR PUSTAKA}

Badara, A. (2014). Analisis Wacana. Teori, Metode, dan Penerapannya pada Wacana Media. Jakarta: Kencana Prenada Media Group.

Haryatmoko (2017). Critical Discourse Analysis (Analisis Wacana Kritis). Landasan Teori, Metodologi, dan Penerapan. Jakarta: PT RajaGrafindo Persada.

Herdiansyah, H. (2013). Wawancara, Observasi, dan Focus Groups Sebagai Instrumen Penggalian Data Kualitatif. Jakarta: PT RajaGrafindo Persada.

Ida, R. (2014). Metode Penelitian, Studi Media dan Kajian Budaya. Jakarta: Prenada Media Group.

Lubis, A. Y. (2016). Pemikiran Kritis Kontemporer. Dari Teori Kritis, Cultural Studies, Feminisme, Postkolonial Hingga Multikulturalisme. Jakarta: PT RajaGrafindo Persada.

Nasrullah, R. (2016). Media Sosial, Perspektif Komunikasi, Budaya, dan Sosioteknologi. Bandung: PT Remaja Rosdakarya. 